\title{
Genetical identification and morphological description of the larvae and juveniles of Porocottus leptosomus (Pisces: Cottidae) from Korea
}

\author{
Ui Cheol Shin ${ }^{1,3}$, Yeon Kyu Jeong ${ }^{1}$, Sang Chul Yoon², Kwang Ho Choi ${ }^{1}$ and Jin-Koo Kim ${ }^{3^{*}}$
}

\begin{abstract}
The larvae and juveniles of Porocottus leptosomus belonging to the family Cottidae were collected $(n=95,3.9-16.5 \mathrm{~mm}$ in body length, BL) from Busan, Korea, in March 2015. The larvae and juvenile were identified using DNA barcoding as P. leptosomus, and their morphological description was presented in detail. The yolk-sac larvae (3.9-5.6 mm BL) body was slightly compressed, the head was large, the eye was round and large, and the anus was before the middle of the body. The preflexion larvae (5.2-10.0 mm BL) body length drastically increased; caudal fin rays began to occur. The flexion larvae (9.4-11.8 mm BL) notochord flexion started; dorsal, pectoral, and anal fin rays began to occur; pelvic fin buds are seen; they possessed a pair of parietal spine; and a pair of supraocular cirri was first to develop. At $12 \mathrm{~mm} \mathrm{BL}$, the notochord was completely flexed. The larva stage (3.9-12.6 mm SL) had the stellate melanophores in the head, isthmus, gut, and tail (along to the ventral midline). During the juvenile stage (11.4-16.5 mm BL), melanophores covered the head and began to form five black bands on the side of the body. The larvae of $P$. leptosomus spent pelagic life, but moved to the bottom during the juvenile stage. The larvae and juveniles of $P$. leptosomus differ from other cottid larval fishes by body shape, melanophore head pattern, and spine development. P. leptosomus can be distinguished from Porocottus allisi by morphological development and the occurrence of larval fish: preopercular spine development, melanophore pattern, and caudal fin development.
\end{abstract}

Keywords: Porocottus leptosomus, Fish larvae, Juvenile, Morphological development, Korea

\section{Introduction}

The family Cottidae, in the suborder Cottoidei, contains 282 species and 70 genera worldwide, with 39 species and 20 genera in Korea (National Institute of Biological Resources) 2011; Song et al. 2012; Nelson 2016; Shin et al. 2016). This family is widely distributed worldwide except in the Indian Ocean, showing greatest species diversity occurs in the North Pacific (Watanabe 1969; Richardson 1981; Eschmeyer 1965; Yabe 1985; Cartwright 2009; Knope 2013). They are not commercially important, but the cottid fishes are important components of North Pacific coastal ecosystems (Cartwright 2009; Blood and Matarese 2010).

\footnotetext{
* Correspondence: taengko@hanmail.net

${ }^{3}$ Department of Marine Biology, Pukyong National University, Busan 48513, South Korea

Full list of author information is available at the end of the article
}

The cottid fishes are an oviparous fish, which generally produce demersal eggs and provide parental care or deposit their eggs in concealed spaces or cavities (Matarese et al. 1989; Kendall Jr. 2011). The larvae and juveniles are generally characterized by a slender body, short snout, fan-like pectoral fin, four or serrate preopercular spines, and heavy pigment on dorsal surface of the gut, nape, and along the postanal ventral midline (Kendall Jr. 2011; Okiyama 2014). Larvae and juveniles of cottid fishes can be identified based on pigmentation pattern, head spine development, cirri development, and preanal length (Richardson 1981; Kendall Jr. 2011; Okiyama 2014). However, the systematics and life histories of the most cottid species are poorly known (Matarese et al. 1989; Cartwright 2009; Blood and Matarese 2010). The DNA barcoding can help resolve the difficulties on species identification. 
Porocottus leptosomus (Muto et al. 2002) was originally described as a new species based on specimens collected from Taean, eastern margin of the Yellow Sea. P. leptosomus has been collected from the Shandong Peninsula, China, and the intertidal zone around Gyeongju, Gyeongsangbuk-do, Korea, in recent years; its distribution was newly added to the western margin of the Yellow Sea and the Korea Strait (Choi and Yang 2008; Choi et al. 2008). This species must be protected because the habitat of $P$. leptosomus is highly restricted, requiring further researches on population genetics and ecology.

Larval fish identification of the family Cottidae has caused confusion as the systematics and early life histories of most species are poorly known (Cartwright 2009). It is needed for the study on the morphological development of larval stages to clarify the species identification. There are few studies on P. leptosomus except for reports on species occurrence.

In this study, the larvae and juveniles of $P$. leptosomus were identified using DNA barcoding, and their morphological description was presented in detail.

\section{Materials and methods}

A total of 95 larvae and juveniles of P. leptosomus [3.9$16.5 \mathrm{~mm}$ body length (BL)] were collected in Cheongsapo and Dadaepo, Busan, Korea, on March, 2015, and January, 2016, utilizing a scoop net (Fig. 1). They were preserved in
95\% ethanol. The larvae and juveniles of P. leptosomus are deposited at the Ichthyoplankton Laboratory of Pukyong National University (PKUI).

Total DNA was extracted from eyeballs of larvae and juveniles $(n=21)$ and from muscle tissue of adult collected from Taean (type locality) using a DNA Extraction Kit (Bioneer Trade Co. LTD, Korea). The specimens were studied using VF2 (5'-TCA ACC AAC CAC AAA GAC ATT GGC AC-3') and FishR2 (5'-ACT TCA GGG TGA CCG AAG AAT CAG AA-3') primers, which amplify the mitochondrial DNA cytochrome oxidase subunit I (COI) (Ward et al. 2005; Ivanova et al. 2007). The condition of PCR and purification of PCR products were followed by the method of Ward et al. (2005), with some modification. DNA was sequenced on an ABI 3730XL Sequencer (Applied Biosystems, Foster City, CA, USA) using the ABI PRISM BigDye Terminator v3.1 Ready Reaction Cycle Sequencing Kit (Applied Biosystems). The sequences were aligned using ClustalW (Thompson et al. 1994) in BioEdit ver. 7 (Hall 1999). Genetic distances were calculated using the Kimura two-parameter method (Kimura 1980) in MEGA 6 (Tamura et al. 2013). A neighbor-joining (NJ) tree was constructed with the Kimura two-parameter method (Kimura 1980) and 1000 bootstrap replications using MEGA 6 (Tamura et al. 2013).

Morphological developments were observed using a microscope (Olympus SZX16, Japan). Measurements were

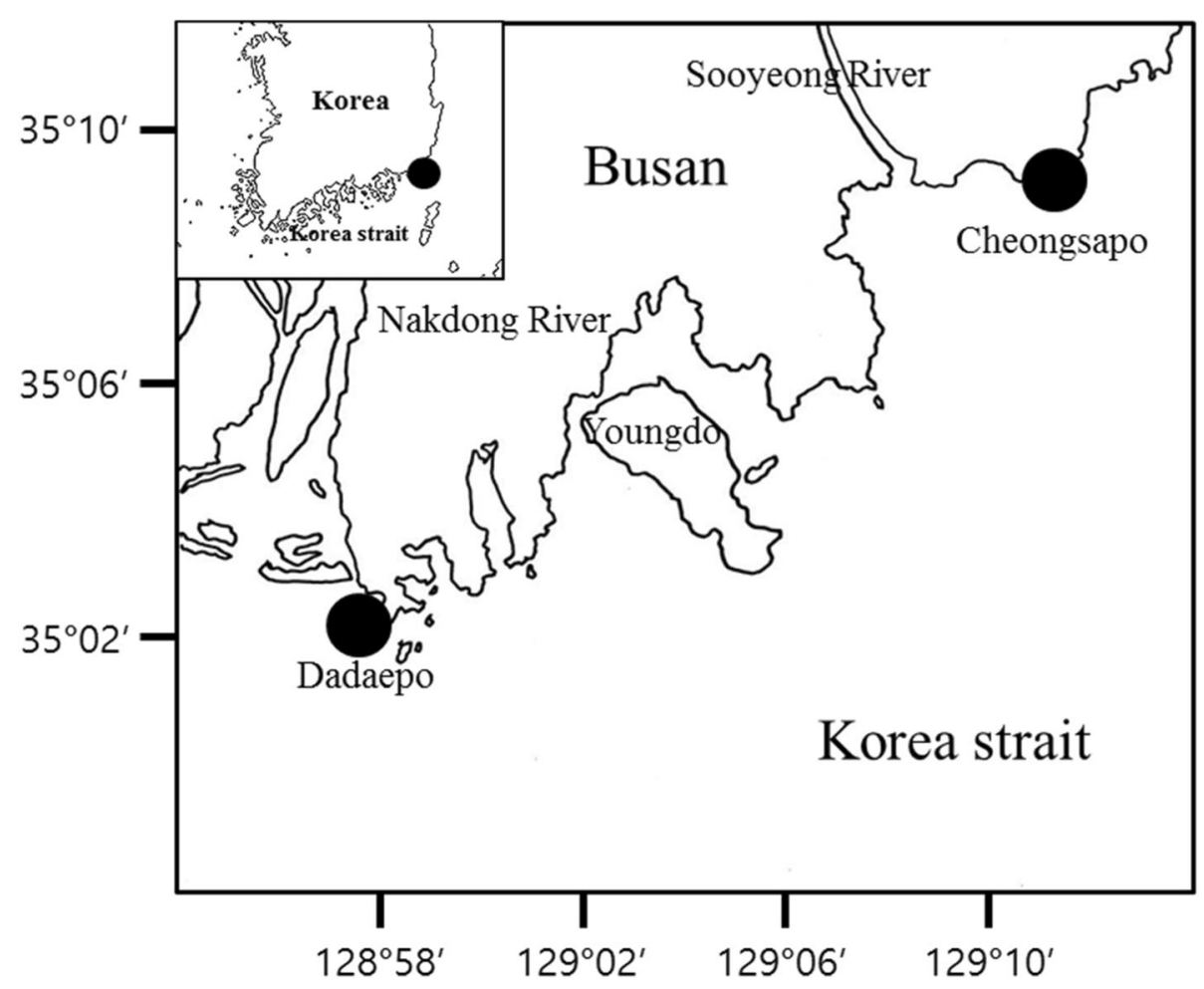

Fig. 1 Map showing the sampling area of larvae and juveniles of Porocottus leptosomus 
made according to the methods of Eschmeyer (1999) (body parts were measured to the nearest $0.1 \mathrm{~mm}$ ). The terminology of developmental stages followed Kim et al. (2011), the terminology of head spination followed Moser and Ahlstrom (1978), and the terminology of head cirri followed Muto et al. (1994). In addition, we subdivided the pigmentation patterns of preflexion larvae into 16 positions, a modification of the 26 positions suggested by Kendall and Lenarz (1986) (Fig. 2).

Growth patterns during the early development were modeled by a power function of $\mathrm{BL}$ and the allometric patterns were described by the growth coefficient in the equation $Y=a X^{b}$, where $Y$ is the dependent variable (measured characteristic), $X$ the independent variable (BL), $a$ is the intercept, and $b$ is the allometric coefficient. Isometric growth occurred when $b=1$; allometric growth was positive when $b>1$ and negative when $b<1$. In addition, linear regressions were performed on log-transformed data and the inflection points were calculated. Inflection points are the $X$ values where the slope of growth changes.

\section{Materials examined}

Examined materials included yolk-sac larvae $(3.9-5.6 \mathrm{~mm}$ BL, $n=10$; PKUI 400, 470, 471, 473, 474, 506, 508, 526528), preflexion larvae $(5.2-10.0 \mathrm{~mm}$ BL, $n=52$; PKUI $361,469,472,475-505,507,509-525)$, flexion larvae (9.4-11.8 mm BL, $n=14$; PKUI 359, 360, 362, 401-406, $412-414,416,418)$, postflexion larvae $(11.8-12.6 \mathrm{~mm} \mathrm{BL}$, $n=5$; PKUI 407, 408, 411, 415, 417), and juveniles (11.4$16.5 \mathrm{~mm} \mathrm{BL}, n=14$; PKUI 351-358, 363-366, 409, 410).

mtDNA COI sequences of 6 species of the family Cottidae were obtained from PKU and the National Center for Biotechnology Information (NCBI) as follows: Porocottus leptosomus (PKU 8158, 13005), Porocottus allisi (PKU 7742), Icelinus quadriseriatus (KF929994), Asemichthys taylori (KP827345), Trachidermus fasciatus (JX029074), Icelinus borealis (JQ354140).

\section{Results}

\section{Molecular identification}

A total of 500 base pairs of the mtDNA COI sequences of 21 larvae and juveniles of P. leptosomus (KY305147-
305167) were compared with those of 6 other cottid species including $P$. leptosomus adults collected from type locality and Busan (Fig. 3). The neighbor-joining tree showed that the 21 larvae and juveniles were clustered together with adults of $P$. leptosomus (pairwise genetic distance, $d=0.000-0.006$ ) (Fig. 2). The 21 larvae and juveniles differed from Porocottus allisi (Jordan and Starks, 1904) $(d=0.125-0.132)$. The 21 larvae and juveniles differed from other species of the family Cottidae: Icelinus quadriseriatus $(d=0.158-0.163)$, Asemichthys taylori $(d$ $=0.186-0.191)$, Trachidermus fasciatus $(d=0.208-$ $0.211)$, Icelinus borealis $(d=0.175-0.178)$. The 21 larvae and juveniles examined in this study were identified as P. leptosomus.

\section{Morphological development}

Drawings of larvae and juveniles are shown in Figs. 4 and 5. Measurements are shown in Fig. 6 and Table 1. The yolk-sac larvae (3.9-5.6 mm BL) body was slightly compressed; head was large; eye was round and large; mouth was large, oblique, and subterminal; posterior end of the upper jaw was not reaching the middle of the eye; they have a pair of nostrils; origin of dorsal fin was vertically above the origin of the pectoral fin; anus was before the middle of the body; and the origin of the anal fin was behind the anus. The preflexion larvae (5.2-10.0 $\mathrm{mm} \mathrm{BL}$ ) body length drastically increased, they have a slender body, and all body proportions decreased (Fig. 7). The flexion larvae have $9.4-11.8 \mathrm{~mm} \mathrm{BL}$. At $9.5 \mathrm{~mm} \mathrm{BL}$, notochord flexion started; body proportions except the eye diameter increased; the eye diameter steadily decreased; and they have two pairs of circular nostrils. The postflexion larvae have $11.8-12.6 \mathrm{~mm} \mathrm{BL}$. At $12 \mathrm{~mm} \mathrm{BL}$, the notochord was completely flexed, maxilla has teeth, they have two pairs of nostrils, and both nostrils have a short tube. Juveniles (11.4-16.5 mm BL) head length increased; posterior end of upper jaw was reaching the middle of the eye; lateral line scales begin to form when four black bands are on the side of the body.

The yolk-sac larvae (3.9-5.6 mm BL) lacked head spines (Fig. 4a), but at $5.5 \mathrm{~mm} \mathrm{BL}$, they possessed four preopercular spines (Fig. 4b). The flexion larvae (9.4-

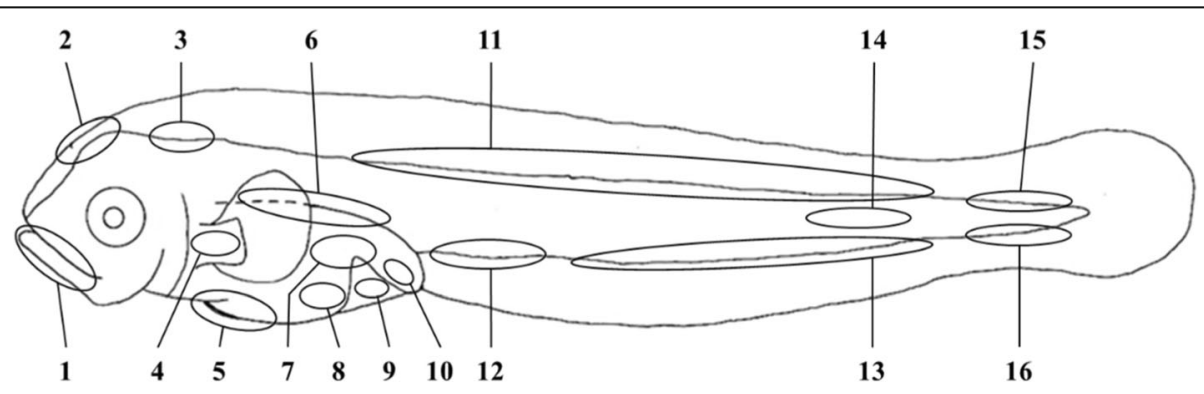

Fig. 2 Pigment position of a preflexion larva. The numbering of position modified from Kendall and Lenarz (Kendall Jr and Lenarz 1986) 


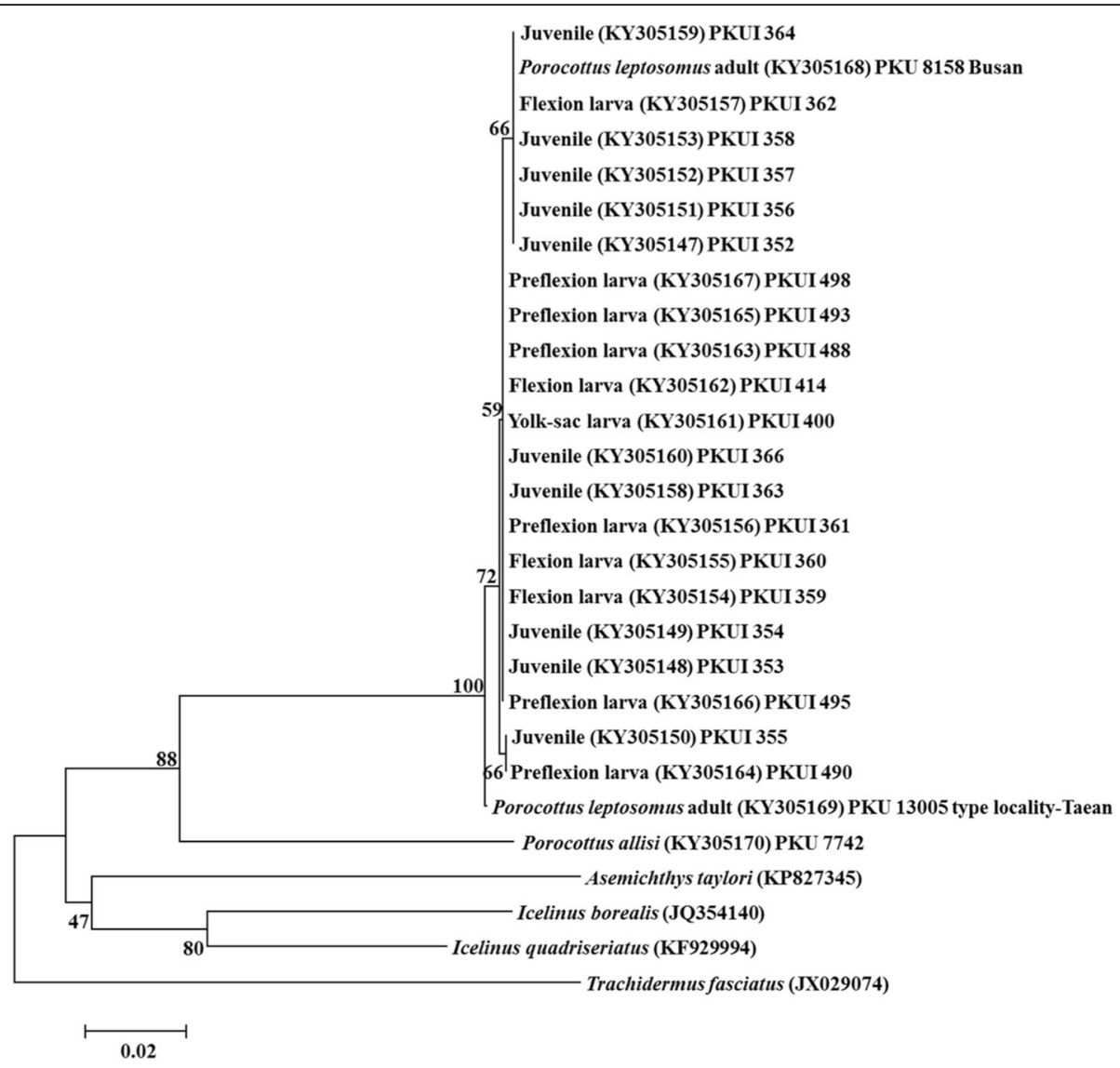

Fig. 3 Neighbor joining tree showing the relationships among larvae and juveniles of Porocottus leptosomus collected from Busan, and $P$. leptosomus adult collected from Taean (type locality) and five cottid species. Numbers at branches indicate bootstrap probabilities in 1000 bootstrap replications. Bar indicates genetic distance of 0.02

$11.8 \mathrm{~mm} \mathrm{BL}$ ) possessed a pair of parietal spine (Fig. 4c). At $10.5 \mathrm{~mm} \mathrm{BL}$, the fourth preopercular spine was bicuspid (Fig. 4d). The postflexion larvae (11.8-12.6 mm BL) had similar spines but they developed spines (Fig. 5a). During the juvenile stage (11.4-16.5 mm BL), the first and second preopercular spines were well developed and curved upward (Fig. 5b, c).

At $11 \mathrm{~mm} \mathrm{BL}$, a pair of supraocular cirri was first to develop (Fig. 4d). During the postflexion larva stage (11.8-12.6 mm BL), supraocular cirri became elongated (Fig. 5a). During the juvenile stage (11.4-16.5 mm BL), the tip of cirri became branched (Fig. 5b, c).

The yolk-sac larvae $(3.9-5.6 \mathrm{~mm} \mathrm{BL})$ possessed a primordial finfold; pectoral fin looked like a fan and lacked real fin rays, and the pectoral fin was short, not reaching the anus (Fig. 4a). At $6.5 \mathrm{~mm} \mathrm{BL}$, caudal fin rays began to occur (Fig. 4b). At $9.5 \mathrm{~mm} \mathrm{BL}$, dorsal, pectoral, and anal fin rays began to occur; pelvic fin buds are seen (Fig. 4c). At $11.5 \mathrm{~mm} \mathrm{BL}$, pelvic fin rays began to develop, ray segmentation was initiated in the caudal fin, all fin rays were reaching the margin of the fin, and the second dorsal and anal fins were separated from the caudal fin (Fig. 4d).
During the postflexion larva stage (11.8-12.6 mm BL), the development of dorsal fin spines was completed; the dorsal and anal fins were separated from the caudal fin (Fig. 5a). During the juvenile stage (11.4-16.5 mm BL), the numbers of fin spine and ray were equal to those in adults: VI VII-18 19 dorsal, 12 14 anal, 15 16 pectoral, and I, 3 pelvic. All soft fin rays were segmented (Table 2).

The yolk-sac larvae $(3.9-5.6 \mathrm{~mm} \mathrm{BL})$ had the stellate melanophores in head, isthmus, gut, and tail (along to the ventral midline) (Fig. 4a). The preflexion larvae (5.2$10.0 \mathrm{~mm} \mathrm{BL}$ ) showed a similar melanophore pattern with that of yolk-sac larvae (Fig. 4b). The flexion larvae (9.4$11.8 \mathrm{~mm} \mathrm{BL}$ ) had the spotted-shaped melanophores in the head (Fig. 4c, d). The postflexion larvae (11.8-12.6 $\mathrm{mm} \mathrm{BL}$ ) had spotted-shaped melanophores in the gut; all posflexion larvae except two specimens had spotted-shaped melanophores in the head (Fig. 5a). During the juvenile stage (11.4-16.5 mm BL), melanophores covered the head and began to form five black bands on the side of the body (Fig. 5b, c).

The percentage of pectoral fin length (PL) to $\mathrm{BL}$ increased with size, and the percentage of eye diameter 


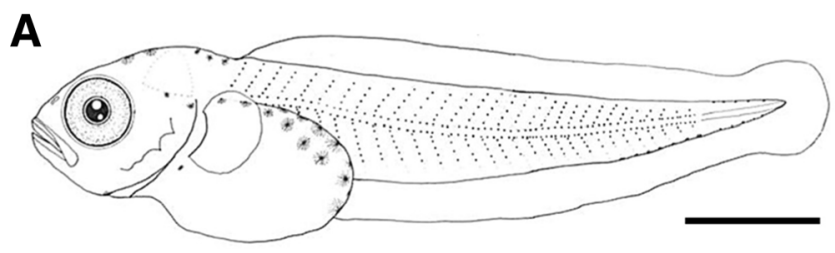

B
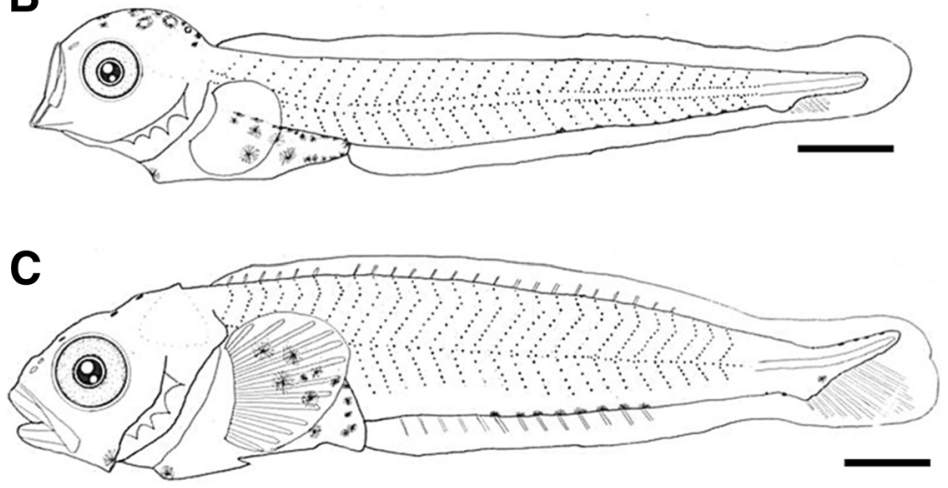

D

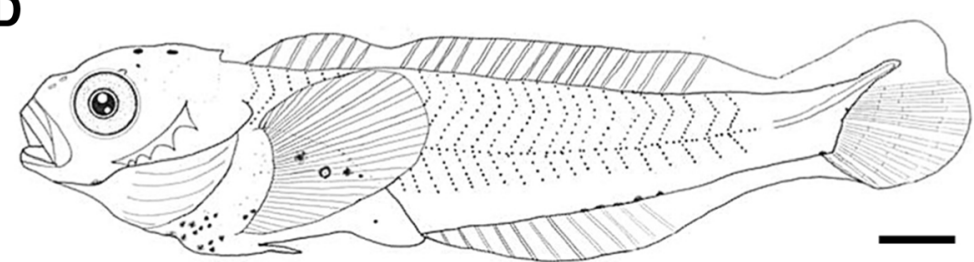

Fig. 4 Drawings of larvae of Porocottus leptosomus. a Yolk-sac larva (5.6 mm BL) (PKUI 400). b Preflexion larva (8.5 mm BL) (PKUI 491). c Flexion larva (10.5 mm BL) (PKUI 406). d Flexion larva (11.5 mm BL) (PKUI 403). Bars $1 \mathrm{~mm}$

(ED) to head length (HL) decreased with size (Fig. 7). The percentage of preanal length (PAL), body depth (BD), and head length (HL) to BL decreased before notochord flexion. These percentages showed a further increase at the flexion larva stage (Fig. 7). The percentages of PAL, BD, and $\mathrm{HL}$ to $\mathrm{BL}$ during the preflexion stage are plotted (Fig. 7).

\section{Discussion}

A total of 500 base pairs of the mtDNA COI gene of 21 larvae and juveniles of $P$. leptosomus were compared with those of 6 other cottid species (Fig. 3). The 21 larvae and juveniles examined in this study were identified as $P$. leptosomus. The larvae and juveniles belong to the genus Porocottus for having a slender body, a short snout, a fan-like pectoral fin, four or serrate preopercular spines, and heavy pigment on dorsal surface of the gut, nape, and epural, and along the postanal ventral midline (Kendall Jr. 2011; Okiyama 2014). These characters were well corresponded to our specimens.

The occurrence season of $P$. leptosomus larvae was similar to that of Hexagrammos otakii and Furcina ishikawae. So compared with these species, P. leptosomus can be misidentified as Hexagrammos otakii and $F$. ishikawae by the following characters such as fin development and melanophore pattern: fin development (around $12.5 \mathrm{~mm} \mathrm{BL}$ in P. leptosomus vs. over $19 \mathrm{~mm} \mathrm{BL}$ in H. otakii vs. $17 \sim 18 \mathrm{~mm}$ BL in F. ishikawae), melanophore pattern (no melanophores on lateral trunk in $P$. leptosomus vs. melanophores on lateral trunk in $\mathrm{H}$. otakii and F. ishikawae), cirri development (at $11 \mathrm{~mm} \mathrm{BL}$ in P. leptosomus vs. absent in $H$. otakii vs. at $16 \mathrm{~mm} \mathrm{BL}$ in F. ishikawae) (Okiyama 2014). The fin and cirri development of $P$. leptosomus was faster than those of other intertidal fishes. These differences may be survival strategies that have the potential to decrease mortality of the eggs, larvae, and juveniles through camouflage and development of swimming ability.

Matarese et al. (1989) divide the cottid larval fishes in Northeastern Pacific Ocean into eight groups based on morphological characters. The larvae and juveniles of $P$. leptosomus are morphologically similar to the "Myoxocephalus group" in Matarese et al. (1989) based on the following features: slender body, pointed snout, four preopercular spines, melanophore pattern. These results were consistent with the results of morphological classification in Yabe (1985) and the results of molecular phylogeny in Knope (2013). However, the genus Porocottus 

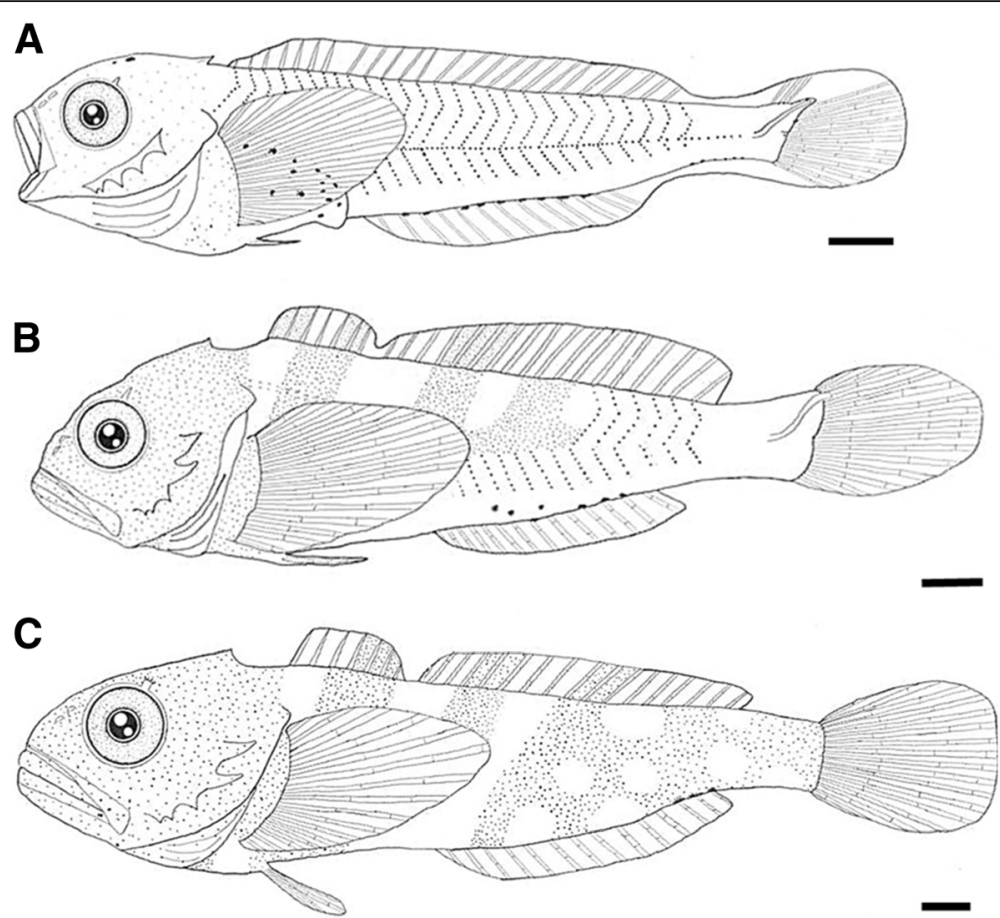

Fig. 5 Drawings of larvae and juveniles of Porocottus leptosomus. a Postflexion larva (12.3 mm BL) (PKUI 408). b Juvenile (13.3 mm BL) (PKUI 358). c Juvenile (16.5 mm BL) (PKUI 351). Bars $1 \mathrm{~mm}$
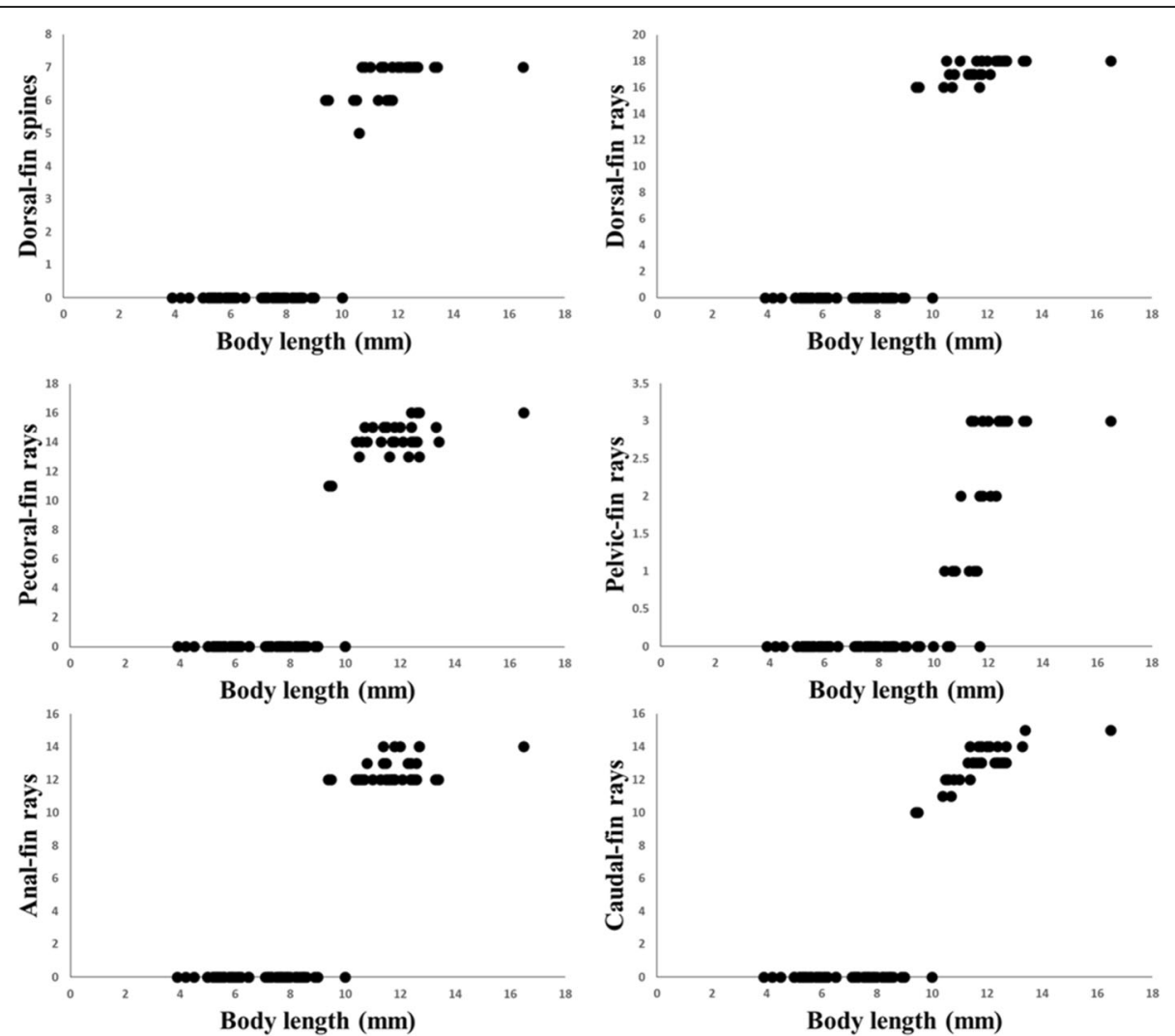

Fig. 6 Relative growth of fin count in larvae and juveniles of Porocottus leptosomus 
Table 1 Measurements of larvae and juveniles of Porocottus leptosomus. Values for each body proportion are expressed as percentage of body length $(\mathrm{BL})$ or head length $(\mathrm{HL})$ : mean and range

\begin{tabular}{|c|c|c|c|c|c|}
\hline & Yolk sac & Preflexion & Flexion & Postflexion & Juveniles \\
\hline Number of specimens & 10 & 52 & 14 & 5 & 14 \\
\hline Body length (mm) & $3.9-5.6$ & $5.2-10$ & $9.4-11.8$ & $11.8-12.6$ & $11.4-16.5$ \\
\hline Preanal length/SL (\%) & $\begin{array}{l}38.5-50.0 \\
(44.5)\end{array}$ & $\begin{array}{l}32.9-48.3 \\
(39.3)\end{array}$ & $\begin{array}{l}34.5-50.5 \\
(40.4)\end{array}$ & $\begin{array}{l}41.3-50.0 \\
(44.9)\end{array}$ & $\begin{array}{l}39.8-57.0 \\
(45.8)\end{array}$ \\
\hline Head length/SL (\%) & $\begin{array}{l}20.5-30.0 \\
(26.3)\end{array}$ & $\begin{array}{l}17.3-29.3 \\
(22.5)\end{array}$ & $\begin{array}{l}20.5-33.6 \\
(25.4)\end{array}$ & $\begin{array}{l}24.0-29.7 \\
(26.8)\end{array}$ & $\begin{array}{l}23.6-35.2 \\
(29.5)\end{array}$ \\
\hline Body depth/SL (\%) & $\begin{array}{l}17.9-27.8 \\
(23.0)\end{array}$ & $\begin{array}{l}15.6-27.6 \\
(21.0)\end{array}$ & $\begin{array}{l}17.1-27.4 \\
(21.4)\end{array}$ & $\begin{array}{l}21.5-25.4 \\
(23.2)\end{array}$ & $\begin{array}{l}19.5-26.1 \\
(22.9)\end{array}$ \\
\hline Pectoral fin length/SL (\%) & $\begin{array}{l}6.6-12.0 \\
(8.6)\end{array}$ & $\begin{array}{l}8.5-13.3 \\
(10.4)\end{array}$ & $\begin{array}{l}12.0-25.3 \\
(18.4)\end{array}$ & $\begin{array}{l}19.0-23.2 \\
(21.1)\end{array}$ & $\begin{array}{l}17.3-26.1 \\
(22.3)\end{array}$ \\
\hline Snout length/HL (\%) & $\begin{array}{l}13.3-27.3 \\
(19.6)\end{array}$ & $\begin{array}{l}12.5-26.3 \\
(20.3)\end{array}$ & $\begin{array}{l}16.7-29.6 \\
(23.2)\end{array}$ & $\begin{array}{l}23.3-27.6 \\
(25.0)\end{array}$ & $\begin{array}{l}20.0-26.3 \\
(23.2)\end{array}$ \\
\hline Eye diameter/HL (\%) & $\begin{array}{l}35.7-63.6 \\
(46.3)\end{array}$ & $\begin{array}{l}29.4-46.7 \\
(39.3)\end{array}$ & $\begin{array}{l}25.0-41.7 \\
(35.6)\end{array}$ & $\begin{array}{l}29.4-34.5 \\
(32.4)\end{array}$ & $\begin{array}{l}28.2-38.7 \\
(35.0)\end{array}$ \\
\hline
\end{tabular}

can be distinguished from the genus Myoxocephalus by preopercular spine shape and fin development: the genus Myoxocephalus develop four preopercular spines, and then preopercular spines except the first and second preopercular spine disappear, but $P$. leptosomus have four preopercular spines during larval development; the fin completion of P. leptosomus is faster than that of the genus Myoxocephalus (at $12 \mathrm{~mm} \mathrm{BL}$ in P. leptosomus vs. over $14 \mathrm{~mm} \mathrm{BL}$ in the genus Myoxocephalus) (Matarese et al. 1989; Okiyama 2014). The larvae and juveniles of most cottids generally developed $4 \sim 5$ preopercular spines and then reduced the size or number of preopercular spines (Okiyama 2014). In most of adult cottids, they have a large first preopercular spine which is simple

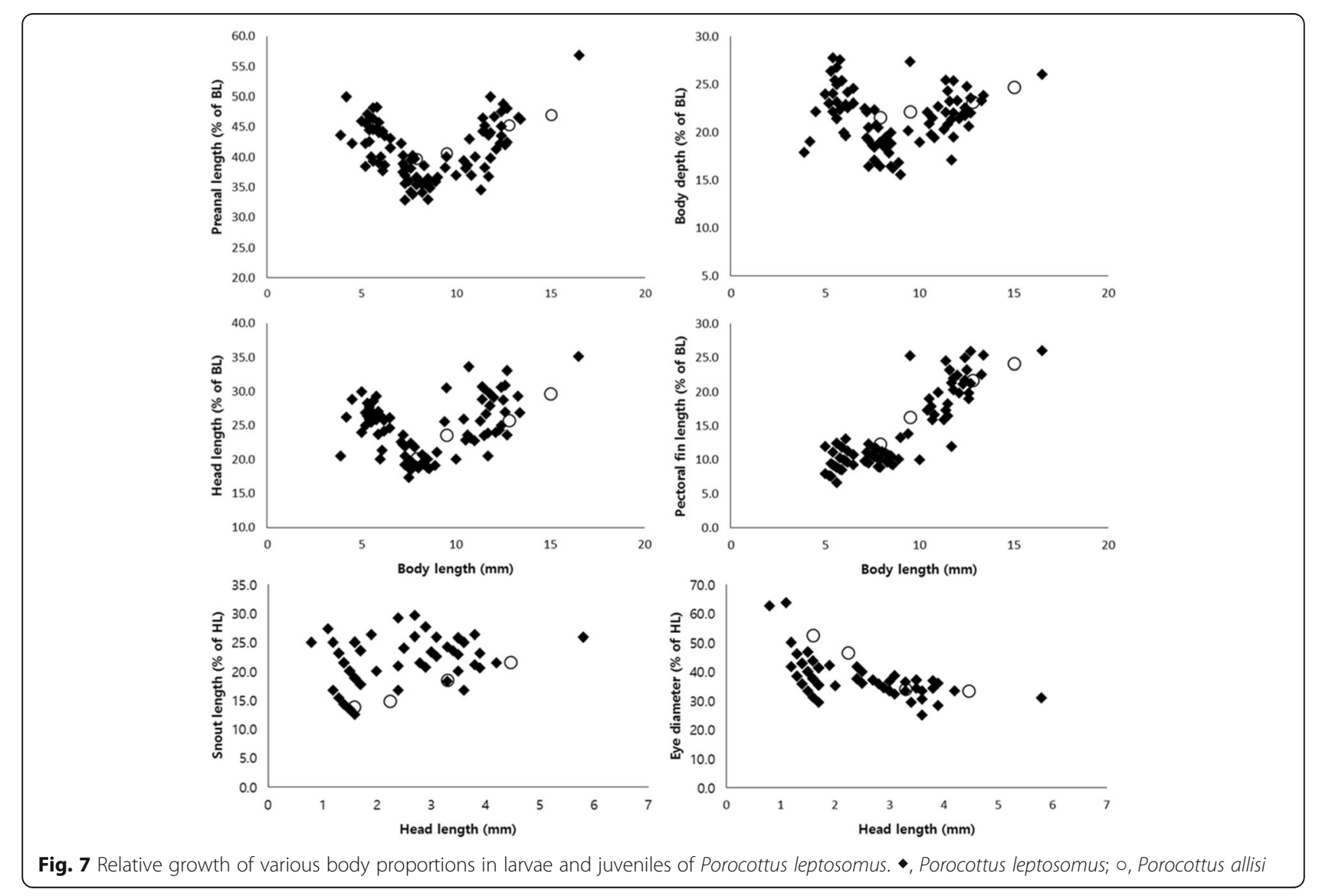


Table 2 Fin rays, head spines, and head cirri development in Porocottus leptosomus

\begin{tabular}{|c|c|c|c|c|c|c|c|c|}
\hline \multirow[t]{2}{*}{ Elements } & \multirow{2}{*}{$\begin{array}{l}\text { Yolk-sac larvae } \\
3.9\end{array}$} & \multicolumn{2}{|c|}{ Preflexion larvae } & \multicolumn{2}{|c|}{ Body length (mni) Flexion larvae } & \multirow{2}{*}{$\begin{array}{l}\text { Postflexion larvae } \\
11.8\end{array}$} & \multicolumn{2}{|c|}{ Juvenile } \\
\hline & & 5.5 & 6.2 & 9.5 & 10.8 & & 12.4 & 16.5 \\
\hline \multicolumn{9}{|l|}{ Fin rays } \\
\hline Dorsal-fin rays & & & & $\mathrm{Vl}, 16$ & VIII, 17 & VII, 18 & VII, 18 & VII, 18 \\
\hline Anal-fin rays & & & & 12 & 13 & 12 & 12 & 14 \\
\hline Pectoral-fin rays & & & & 11 & 14 & 14 & 15 & 15 \\
\hline Pelvic-fin rays & & & & Bud & Incipient & 1,2 & 1,3 & 1,3 \\
\hline Caudal-fin rays & & & w.anlage & 10 & 12 & 13 & 15 & 15 \\
\hline \multicolumn{9}{|l|}{ Head spines } \\
\hline Parietal spine & & & & $\mathrm{O}$ & $\mathrm{O}$ & $\mathrm{O}$ & $\mathrm{O}$ & $\mathrm{O}$ \\
\hline Preopercular spine & 2 & 4 & 4 & 4 & $4 b$ & $4 b$ & $4 b$ & $4 b$ \\
\hline \multicolumn{9}{|l|}{ Head cirri } \\
\hline Supraocular cirri & & & & & Bud & Incipient & $\mathrm{O}$ & $\mathrm{O}$ \\
\hline
\end{tabular}

$w$ Indicates weak; $b$ Indicates bicuspid

or highly modified (Yabe 1985; Nakabo and Kai 2013). The preopercular spine development of P. leptosomus will be similar to those of other cottid. After juvenile stage, $P$. leptosomus expected to reduce size or number of preopercular spines. Melanophore pattern of preflexion larvae compared with these of other cottid species (Table 3). Compared with the genus Myoxocephalus which is close to the genus Porocottus, P. leptosomus having melanophores in ventral abdominal and hypural has no melanophores in the upper jaws, nape, and dorsal contour. As in other species of Cottidae, larvae and juveniles of P. leptosomus showed that the percentage of PL to $\mathrm{BL}$ increased with size and the percentage of ED to
HL decreased with size (Sado et al. 2005; Blood and Matarese 2010; Okiyama 2014; Fig. 7). The percentages of PAL, BD, and $\mathrm{HL}$ to $\mathrm{BL}$ during larval development are plotted because the body length rapidly grows in the preflexion larvae stage (Figs. 7 and 8). The experimental values of PAL, BD, and $\mathrm{HL}$ continue to increase with size (Fig. 8).

Compared with $P$. allisi, counts and measurements have no difference (Han and Kim 1997; Okiyama 2014; Fig. 7). But P. leptosomus can be distinguished from $P$. allisi by morphological development and the occurrence of larval fish: preopercular spine development (four spines in P. leptosomus vs. spines increases from two to

Table 3 Comparison of pigmentation pattern in preflexion larvae of 14 cottid fishes

\begin{tabular}{|c|c|c|c|c|c|c|c|c|c|c|c|c|c|c|c|c|c|}
\hline \multirow[t]{3}{*}{ Species } & \multicolumn{16}{|c|}{ Melanophore position } & \multirow[t]{3}{*}{ References } \\
\hline & \multirow[t]{2}{*}{1} & \multirow[t]{2}{*}{2} & \multirow[t]{2}{*}{3} & \multirow[t]{2}{*}{4} & \multirow[t]{2}{*}{5} & \multirow[t]{2}{*}{6} & \multirow[t]{2}{*}{7} & \multirow[t]{2}{*}{8} & \multirow[t]{2}{*}{9} & \multirow{2}{*}{$\begin{array}{l}1 \\
0\end{array}$} & \multirow{2}{*}{$\begin{array}{l}1 \\
1\end{array}$} & \multirow{2}{*}{$\begin{array}{l}1 \\
2 \\
\end{array}$} & \multirow{2}{*}{$\begin{array}{l}1 \\
3\end{array}$} & \multirow{2}{*}{$\begin{array}{l}1 \\
4\end{array}$} & \multirow{2}{*}{$\begin{array}{l}1 \\
5 \\
\end{array}$} & \multirow{2}{*}{$\begin{array}{l}1 \\
6 \\
\end{array}$} & \\
\hline & & & & & & & & & & & & & & & & & \\
\hline Porocottus leptosomus & 0 & 1 & 0 & 0 & 1 & 1 & 1 & 1 & 1 & 1 & 0 & 0 & 1 & 0 & 1 & 1 & Present study \\
\hline Porocottus allisi & 0 & 1 & 0 & 0 & 1 & 1 & 1 & 1 & 1 & 1 & 0 & 0 & 1 & 1 & 1 & 1 & Okiyama (2014) \\
\hline Myoxocephalus stelleri & 1 & 1 & 1 & 0 & 0 & 1 & 1 & 0 & 0 & 0 & 1 & 1 & 1 & 1 & 0 & 0 & Okiyama (2014) \\
\hline Enophrys diceraus & 0 & 1 & 1 & 0 & 1 & 1 & 1 & 0 & 1 & 1 & 0 & 1 & 1 & 0 & 0 & 1 & Okiyama (2014) \\
\hline Oligocottus maculosus & 0 & 1 & 1 & 0 & 0 & 1 & 0 & 0 & 0 & 0 & 0 & 0 & 1 & 0 & 0 & 1 & Stein (1973) \\
\hline Gymnocanthus herzensteini & 1 & 1 & 1 & 1 & 0 & 1 & 0 & 0 & 1 & 1 & 0 & 1 & 1 & 0 & 0 & 1 & Kyshin (1970) \\
\hline Alcichthys alcicornis & 0 & 1 & 1 & 1 & 1 & 1 & 0 & 1 & 1 & 1 & 0 & 1 & 1 & 0 & 0 & 1 & Okiyama (2014) \\
\hline Furcina ishikawae & 0 & 1 & 1 & 1 & 0 & 1 & 0 & 0 & 0 & 0 & 0 & 0 & 1 & 1 & 0 & 1 & Okiyama (2014) \\
\hline Ocynectes maschalis & 1 & 1 & 1 & 0 & 0 & 1 & 1 & 1 & 1 & 1 & 0 & 0 & 1 & 0 & 0 & 1 & Okiyama (2014) \\
\hline Pseudoblennius marmoratus & 0 & 0 & 1 & 1 & 0 & 1 & 1 & 0 & 0 & 1 & 0 & 0 & 1 & 0 & 0 & 1 & Sado et al. (2005) \\
\hline Icelinus japonicus & 0 & 0 & 0 & 0 & 0 & 1 & 0 & 0 & 0 & 0 & 0 & 0 & 1 & 0 & 0 & 1 & Okiyama (2014) \\
\hline Astrocottus matsubarae & 1 & 1 & 1 & 1 & 1 & 1 & 1 & 1 & 1 & 1 & 1 & 1 & 1 & 1 & 0 & 1 & Okiyama (2014) \\
\hline Cottus pollux & 0 & 0 & 0 & 0 & 1 & 1 & 0 & 1 & 1 & 0 & 0 & 0 & 1 & 0 & 0 & 1 & Kurawaka (1976) \\
\hline Trachidermus fasciatus & 0 & 0 & 0 & 0 & 0 & 1 & 0 & 1 & 0 & 0 & 0 & 1 & 1 & 0 & 0 & 0 & Takeshita et al. (1997) \\
\hline
\end{tabular}



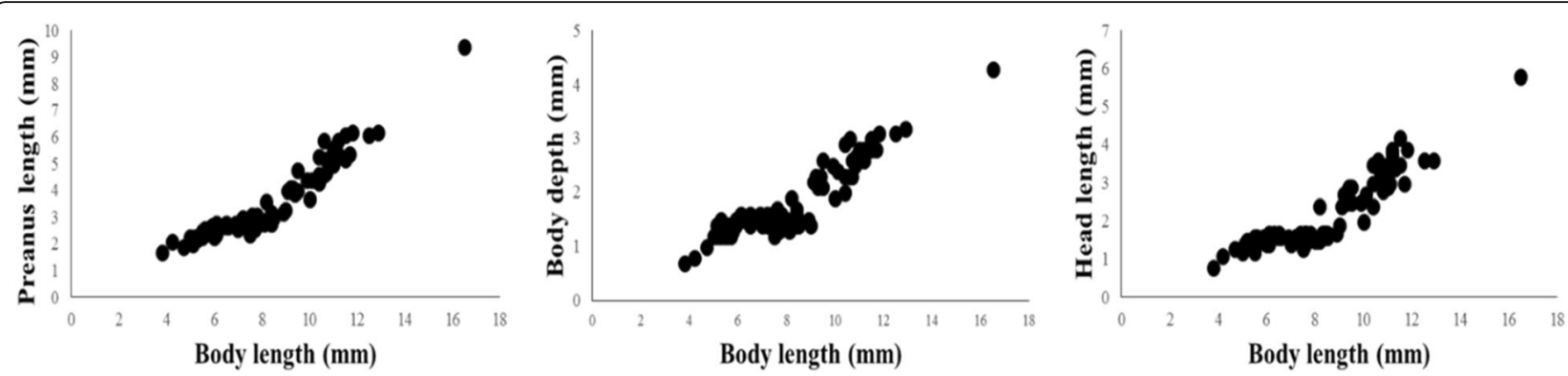

Fig. 8 Relative growth of various experimental of body in larvae and juveniles of Porocottus leptosomus

four in $P$. allisi), notochord flexion (at $10 \mathrm{~mm} \mathrm{TL}$ in $P$. leptosomus vs. at $8.2 \mathrm{~mm}$ TL in $P$. allisi), melanophore pattern (no melanophores on lateral trunk in P. leptoso$m u s$ vs. melanophores on lateral trunk in $P$. allisi), pelvic fin development (buds at $10.3 \mathrm{~mm} \mathrm{TL}$, complete at 13 $\mathrm{mm} \mathrm{TL}$ in $P$. leptosomus vs. buds at $13 \mathrm{~mm} \mathrm{TL}$, complete at $16 \mathrm{~mm}$ TL in $P$. allisi), caudal fin development (first appear at $7 \mathrm{~mm} \mathrm{TL}$, separate other fins at 13 $\mathrm{mm}$ TL in P. leptosomus vs. first appear at $9.5 \mathrm{~mm}$ TL, separate other fins between 16.8 and $20.3 \mathrm{~mm}$ TL in $P$. allisi), the occurrence of larval fish in Busan (from January in P. leptosomus vs. March and April in P. allisi) (Han and Kim 1997; Okiyama 2014; Figs. 4 and 5).

Sculpins are known to display high site fidelity as adults and produce demersal eggs, so gene flow is mediated only through the larvae (Matarese et al. 1989; Yoshiyama et al. 1992; Ramon 2007; Kendall Jr. 2011; Knope 2013). However, the larvae of intertidal species are generally only found near shore and population genetic studies have found low to moderate levels of gene flow among populations (Marliave 1986; Waples 1987; Ramon 2007). According to Choi and Yang (2008) and Choi et al. (2008), Chinese P. leptosomus can be distinguished from the original description in the count of dorsal fin rays (16 rays in Chinese P. leptosomus vs. 18 19 rays in the specimens of holotype and paratypes) (Muto et al. 2002). P. leptosomus population around Korea and China will be divided into two groups and be genetically different from each other. So we need to check Chinese specimens and to reveal the phylogenetic relationship by morphological and molecular analyses.

\section{Conclusions}

The larvae and juveniles of Porocottus leptosomus belonging to the family Cottidae were collected from $\mathrm{Bu}$ san, Korea. The larvae and juvenile of $P$. leptosomus were identified using DNA barcoding as P. leptosomus. The yolk-sac larvae (3.9-5.6 mm BL) body was slightly compressed, head was large, eye was round and large, and anus was before the middle of the body. The preflexion larvae (5.2-10.0 mm BL) body length drastically increased. The flexion larvae $(9.4-11.8 \mathrm{~mm} \mathrm{BL})$ dorsal, pectoral, and anal fin rays began to occur; pelvic fin buds are seen; they possessed a pair of parietal spine; and a pair of supraocular cirri was first to develop. At $12 \mathrm{~mm}$ $\mathrm{BL}$, the notochord was completely flexed. The larva stage (3.9-12.6 mm SL) had the stellate melanophores in the head, isthmus, gut, and tail (along to the ventral midline). During the juvenile stage (11.4-16.5 mm BL), melanophores covered the head and began to form five black bands on the side of the body. P. leptosomus can be distinguished from $P$. allisi by morphological development and the occurrence of larval fish: preopercular spine development, melanophores pattern, caudal fin development.

\section{Acknowledgements \\ This study was supported by National Institute of Fisheries Science, Republic of Korea (R2018027).}

\section{Funding}

This study was supported by National Institute of Fisheries Science, Republic of Korea (R2018027).

\section{Availability of data and materials \\ All datasets analyzed during the current study are available from the corresponding author on reasonable request.}

\section{Authors' contributions}

UCS conducted the research, analyzed the materials, and prepared the draft manuscript. SCY, KHC, and JKK designed and directed the study and finalized the manuscript. All authors read and approved the final manuscript.

Ethics approval and consent to participate

Not applicable.

Consent for publication

Not applicable.

\section{Competing interests}

The authors declare that they have no competing interests.

\section{Publisher's Note}

Springer Nature remains neutral with regard to jurisdictional claims in published maps and institutional affiliations.

\section{Author details}

'Dokdo Fisheries Research Center, National Institute of Fisheries Science, Pohang 37709, South Korea. ${ }^{2}$ Marine and Fisheries Bio-resources Division, Minister of Oceans and Fisheries, Sejong 30110, South Korea. ${ }^{3}$ Department of Marine Biology, Pukyong National University, Busan 48513, South Korea. 
Received: 14 October 2018 Accepted: 7 December 2018

Published online: 24 December 2018

\section{References}

Blood DM, Matarese AC. Larval development and identification of the genus Triglops (Scorpaeniformes: Cottidae). NOAA Prof. Paper, NMFS. 2010;10:1-43.

Cartwright RL. Description of early life history stages of the northern sculpin (Icelinus borealis Gilbert) (Teleostei: Cottidae). Fish Bull. 2009;107:175-86.

Choi Y, Lee HH, Jang JH. Ichthyofauan of the intertidal zone around the nuclear power plants off Sinweolseong, Eastern Coast, Korea. Korean J. Ichthyol. 2008;20:313-7.

Choi Y, Yang ZF. Intertidal fishes from the Shandong Peninsula, China. Korean J Ichthyol. 2008;20:54-60.

Eschmeyer WN. Western Atlantic scorpionfishes of the genus Scorpaena, including four new species. Bull Mar Sci. 1965;15:84-164.

Eschmeyer WN. A field guide to Pacific coast fishes: North America. Houghton Mifflin, Boston: Mass; 1999

Hall TA. BioEdit: a user-friendly biological sequence alignment editor and analysis program for windows 95/98/NT. Nucleic Acids Symp. 1999;41:95-8.

Han KH, Kim YU. Development of larvae and Juvenils of the Cottid fish, Porocottus tentaculatus (Kner). Bull. Yosu. Nat'l fish. Univ. 1997;11(2):119-29.

Ivanova NV, Zemlak TS, Hanner RH, Hebert PDN. Universal primer cocktails for fish DNA barcoding. Mol Ecol Notes. 2007;7:544-8.

Kendall AW Jr, Lenarz WH. Status of early life history studies of northeast Pacific rockfishes. In: Proceedings of the International Rockfish Symposium. Anchorage, Alaska: University of Alaska, Alaska Sea Grant College Program Report AK-SG-87-2; 1986. p. 99-128.

Kendall AW Jr. Identification of eggs and larvae of marine fishes: Tokai Univ Press; 2011.

Kim JK, Ryu JH, Kim S, Lee DW, Choi KH, Oh TY, Hwang KS, Choi JH, Kim JN, Kwun HJ, Ji HS, Oh JN. An identification guide for fish eggs, larvae and juveniles of Korea. Busan: Hanguel Graphics Publishing Co Ltd; 2011.

Kimura M. A simple method for estimating evolutionary rate of base substitutions through comparative studies of nucleotide sequences. J Mol Evol. 1980;16:111-20

Knope ML. Phylogenetics of the marine sculpins (Teleostei: Cottidae) of the North American Pacific coast. Mol Phylogenet Evol. 2013;66:341-9.

Kurawaka K. 1976. Study of speciation in fish. Unpubl. Ph. D. Dissertation, Kyoto Univ., 55: pls. 1-31.

Kyshin K. Embryonic development and larvae of Gymnocanthus herzensteini Jordan and Starks. Japan J Ichthyol. 1970;17:74-9.

Marliave JB. Lack of planktonic dispersal of rocky intertidal fish larvae. Trans Am Fish Soc. 1986;115:149-54.

Matarese AC, Kendall AW Jr, Blood DM, Vinter BM. Laboratory guide to early life history stages of Northeast Pacific fishes. NOAA Tech Rep, NMFS. 1989;80:1-652.

Moser HG, Ahlstrom EH. Larvae and pelagic juveniles of blackgill rockfish, Sebastes melanostomus, taken in midwater trawls off southern California and Baja California. J Fish Res Bd Can. 1978:35:981-96.

Muto F, Choi Y, Yabe M. Porocottus leptosomus sp. Now., from the west coast of Korea, Yellow Sea (Scorpaeniformes: Cottidae). Ichthyol Res. 2002:49:229-33.

Muto F, Yabe M, Amaoka K. A new cottid fish, Artediellus neyelovi, from the southeastern coast of the Oshima Peninsula, Hokkaido, Japan., Jpn. J Ichthyol. 1994:41:275-80.

Nakabo T, Kai Y. Cottidae. In: Nakabo T, editor. Fishes of Japan with pictorial keys to the species. third ed. ToKyo, JP: Tokai Univ Press; 2013. p. 628-50.

Nelson JS. Fishes of the world. fourth ed. New York: Wiley; 2016.

NIBR (National Institute of Biological Resources). National lists of species of Korea. Incheon: Vertebrate Natl. Inst. Biol. Res; 2011. p. 81-6.

Okiyama M. An atlas of the early stage fishes in Japan. Tokyo: Tokai University Press; 2014

Ramon ML. Molecular ecology of intertidal sculpins, PhD thesis, UCSC; 2007.

Richardson SL. Current knowledge of larvae of sculpins (Pisces: Cottidae and allies) in Northeast Pacific genera with notes on intergeneric relationships. Fish Bull. 1981;79(1):103-21.

Sado T, Tachibana Y, Kimura S. Developmental morphology of the cottid fish Pseudoblennius marmoratus. Ichth Res. 2005:52:292-6.

Shin UC, Park JH, Kim JK. New Korean record of Artediellus fuscimentus (Scorpaeniformes: Cottidae). Korean J. Ichthyol. 2016;28(3):207-12.

Song YS, Kim JK, Ryu JH, Kim HJ, Kweon SM, Choi SH. First record of Icelus toyamensis (Scorpaeniformes: Cottidae) from the East Sea, Korea. Korean J Syst Zool. 2012;28(4):304-7.
Stein R. Description of lavoratory-reared larvae of Oligocottus maculosus Girard (Pisces: Cottidae). Copeia. 1973;1973(2):373-7.

Takeshita N, Onikura N, Matsui S, Kimura S. Embryonic, larval and juvenile development of the roughskin sculpin, Trachidermus fasciatus (Scorpaeniformes: Cottidae). Japan. J. Ichthyol. 1997;44(3):257-66.

Tamura K, Stecher G, Peterson D, Filipski A, Kumar S. MEGA6: molecular evolutionary genetics analysis version 6.0. Mol Biol Evol. 2013;30:2725-9.

Thompson JD, Higgins DG, Gibson TJ. CLUSTAL W: improving the sensitivity of progressive multiple sequence alignment through sequence weighting, positions-specific gap penalties and weight matrix choice. Nucleic Acids Res. 1994:22:4673-80.

Waples RS. A multispecies approach to the analysis of gene flow in marine shore fishes. Evolution. 1987:41:385-400.

Ward RD, Zemlak TS, Innes BH, Last PR, Hebert PD. DNA barcoding Australia's fish species. Philos Trans R Soc B. 2005;360:1847-57.

Watanabe M. Fauna Japonica: Cottidae (pisces). Tokyo: Tokyo News Service; 1969.

Yabe M. Comparative osteology and myology of the superfamily Cottoidea (Pisces: Scorpaeniformes), and its phylogenetic classification. Faculty of Fisheries. Hakodate: Hokkaido University; 1985.

Yoshiyama RM, Gaylord KB, Philippar MT, Moore TR, Jordan JR, Coon CC, Schalk $\mathrm{LL}$, Valpey CJ, Tosques I. Homing behavior and site fidelity intertidal sculpins (Pisces: Cottidae). J Exp Mar Biol Ecol. 1992;160:115-30.
Ready to submit your research? Choose BMC and benefit from:

- fast, convenient online submission

- thorough peer review by experienced researchers in your field

- rapid publication on acceptance

- support for research data, including large and complex data types

- gold Open Access which fosters wider collaboration and increased citations

- maximum visibility for your research: over $100 \mathrm{M}$ website views per year

At $\mathrm{BMC}$, research is always in progress.

Learn more biomedcentral.com/submissions 